DOI 10.15393/j10.art.2015.2482

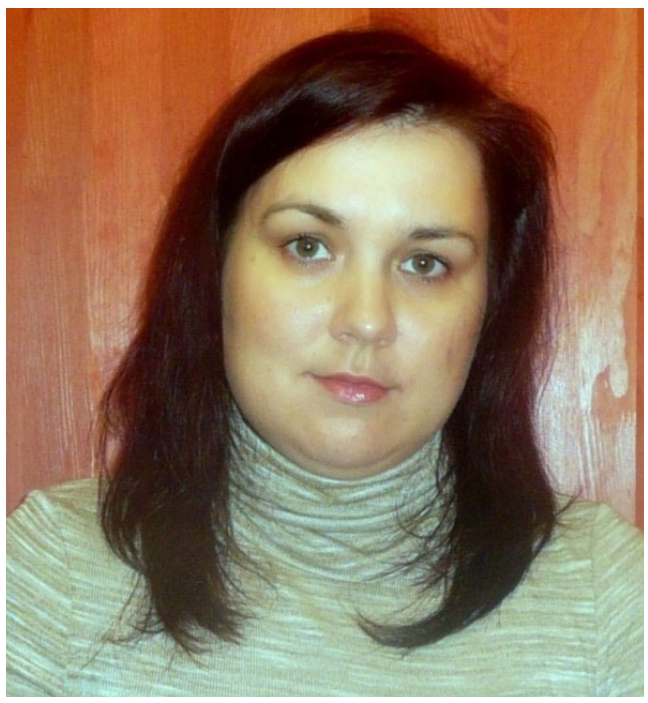

\section{Марина Владимировна Заваркина}

кандидат филологических наук, ведущий редактор Издательства, научный сотрудник кафедры русской литературы и журналистики

Петрозаводский государственный университет

(Петрозаводск, Российская Федерация) mvnikulina@mail.ru

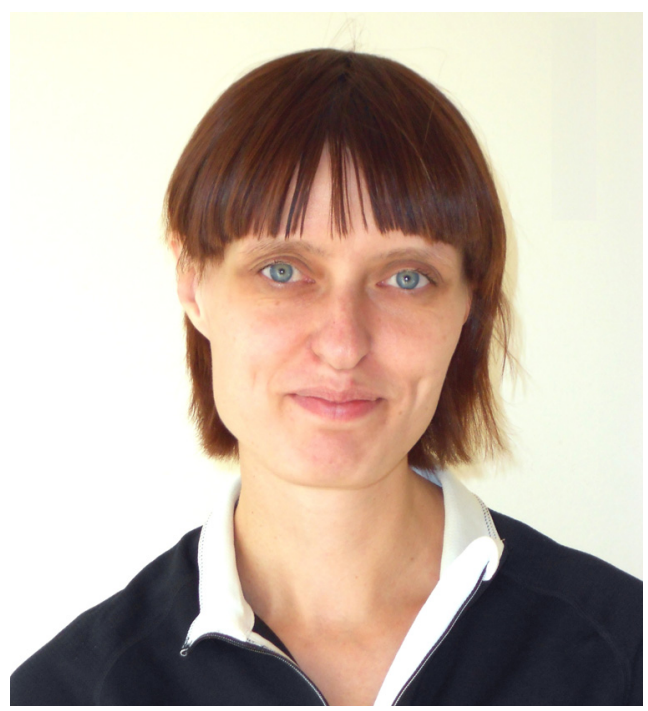

Татьяна Викторовна Панюкова

ведущий редактор Издательства, младший научный сотрудник кафедры русской литературы и журналистики

Петрозаводский государственный университет

(Петрозаводск, Российская Федерация) dostoyevsky@mail.ru

\title{
ИСПРАВЛЕНИЕ ОШИБОК ЧТЕНИЯ В ЗАПИСНОЙ ТЕТРАДИ Ф. М. ДОСТОЕВСКОГО (РГАЛИ. Ф. 212.1.5)*
}

Аннотация. В статье анализируются некоторые случаи ошибочного прочтения творческих записей в записной тетради Ф. М. Достоевского (за декабрь 1865 - октябрь 1867 года) в первой публикации (под редакцией П.Н. Сакулина и Н. Ф. Бельчикова, 1931 год) и в Полном собрании сочинений писателя (Л.: Наука, 1972-1990). Среди ошибок чтения встречается пропуск творческих записей и неправильная их атрибуция (данная тетрадь содержит записи сразу к двум произведениям: романам «Преступление и Наказание» и «Идиот»; к незаконченным замыслам писателя, а также включает расчеты, каллиграфию и т. д.). Чаще всего ошибки чтения возникали, как показано в статье, в результате незнания тонкостей дореволюционной орфографии и неразличения графики писателя. Все анализируемые в статье примеры подкреплены фотографиями рукописи, что позволяет более наглядно представить ошибки чтения в указанных публикациях.

Ключевые слова: Ф. М. Достоевский, записная тетрадь, рукопись, ошибки чтения

аписные книжки и тетради Ф. М. Достоевского раскрывают специфику творческого процесса писателя: по ним мы можем судить о рождении замысла того или иного произведения, образов главных героев и второстепенных персонажей, развитии сюжетных линий. Записная тетрадь 
Достоевского за декабрь 1865 - октябрь 1867 года (РГАЛИ. Ф. 212.1.5) содержит наброски к последней редакции романа «Преступление и Наказание», начальной редакции романа «Идиот», а также ряд незаконченных замыслов писателя. Также она включает описание припадков, записи делового характера, расчеты, графические рисунки, каллиграфию, пробы пера.

Первая публикация тетради была осуществлена в 1931 году: подготовительный материал к роману «Преступление и Наказание» отобрал и опубликовал И. И. Гливенко'; записи, относящиеся к роману «Идиот», П. Н. Сакулин и Н. Ф. Бельчиков ${ }^{2}$. При этом все остальные материалы записной тетради, не относящиеся к этим двум произведениям, остались неопубликованными. Заново тетрадь была прочитана при подготовке Полного собрания сочинений в 30 томах ${ }^{3}$. При прочтении тетради, как в 1930-е, так и в 1970-е годы, были допущены ошибки, которые и проанализированы в данной статье. В работе мы опирались на принципы текстологического анализа, которые разрабатываются современной текстологией (см. ниже список литературы).

В основном, ошибки чтения возникли при расшифровке записей к роману «Преступление и Наказание», однако встречаются ошибки чтения и написанных почти каллиграфическим почерком записей к роману «Идиот».

Самой существенной ошибкой публикаций можно назвать пропуск творческих записей, который неизбежно возникает при отборе материала.

Так, при публикации тетради П. Н. Сакулиным и Н. Ф. Бельчиковым в 1931 году был пропущен отрывок, находящийся на левом поле стр. 2 и расположенный вдоль основного текста (основной текст на странице относится к роману «Преступление и Наказание»). В данном отрывке представлена характеристика Генерала, которая в Д30 атрибутирована как принадлежащая к роману «Идиот». Однако запись была опубликована в Д30 с ошибкой чтения (вместо частицы «не» прочитано местоимение «все»):

«лро Генерал<а.> Самодовольство Генерал $<$. $>$

Это мнгь рпьшительно все равно/

Отдавиль ногу, стукнулся головой. Я не разсердился. Любовь. Мало видюльг,> но глубокъ примпчать. [Эти люди] Ненавистное чувство зачпмъ онъ такъ смотрить и видъ Генерала не <В Д30: все - 9, 164> возбуждаеть въ немъ ненависть. Потомь пришло въ голову что воть этакіе-то люди всегда на равной ногть<,> зависть.

Смолчаль. Генерал<а> уже онъ ненавидтль<.>

Красавииа. Разбиль посуду, заплатить нечпмъ».

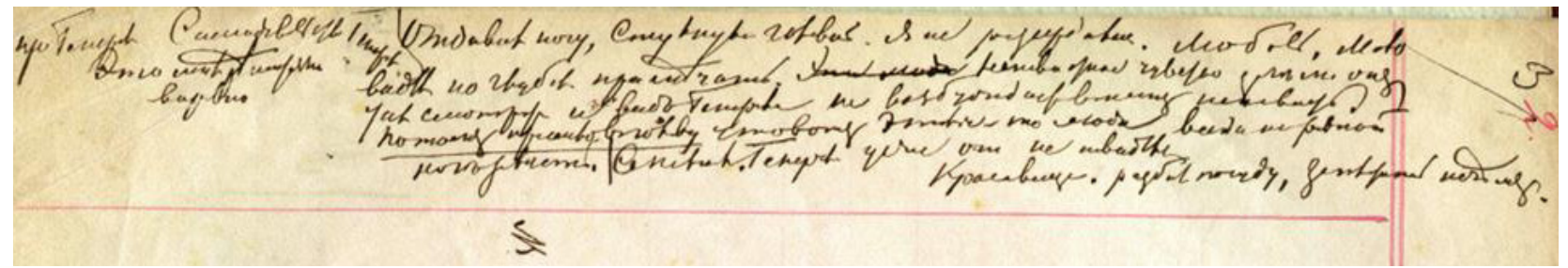


Другая существенная ошибка связана с неправильной атрибуцией записей. Так, записи на стр. 8 тетради в Д30 отнесены к роману «Преступление и Наказание» (см.: Д30, 7, 156, 158). Мы, вслед за К. А. Барштом $[3,105]$ и Б. Н. Тихомировым [19, 146-147], атрибутируем эти записи как относящиеся к роману «Идиот».

Текст прочитан нами несколько иначе, чем в Д30:

«Три дня ргиенья <В Д30: решался - 7, 156>. Измучиль бпднаго, который оть него зависпль и котораго онъ содержаль. Вмгосто застртьл<иться > - женился <В Д30: жениться - 7, 156>».

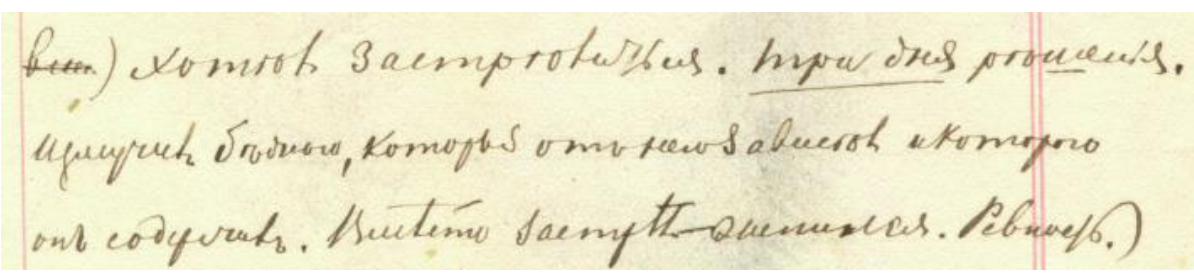

В рукописи четко видны мягкий знак в слове «ргиенья» и буква «л» в слове «женился». Ошибка могла возникнуть вследствие того, что в почерке Достоевского имеется двойственное написание букв «л» и «Т». Сравни, например, на этой же странице написание слов «измучиль»/«женился» и «Ревность»/«хотпльъ».

\section{О букве «ять»}

Если проанализировать на предмет опечаток тексты XIX - начала ХХ веков, изданные ДО и ПОСЛЕ орфографической реформы 19171918 годов (наиболее заметным образом выразившейся в исключении некоторых букв из русского алфавита), то можно заметить в последних появление опечаток совершенно нового типа: пропуски чётко прописанных на концах слов «еров», букв «ять» и «и десятеричное» (либо написания в слове подряд «и восьмеричного» (i) и «и десятеричного» (и), вместо одного последнего: «иі»), замена окончаний «ыя» в прилагательных множественного числа ж. и ср. рода на «ые», окончаний «аго»/«яго» на «ого»/«его», написание приставок «без» и «раз» с буквой «с» на конце и т. д. Подобные опечатки были совершенно не характерны для текстов, изданных до реформы (при том, что, как и в любом печатном издании, опечатки, но другого плана, в них присутствовали). Причиной возникновения этих ошибок становится то, что для современных исследователей дореволюционная графика и грамматика при написании каких-либо слов или словоформ уже явление чужеродное, подобные начертания непривычны, не автоматизированы, не «впитаны с молоком матери», а усвоены чисто внешне, что зачастую и приводит к подобным «сбоям».

Уже в первом издании записной тетради, у П. Н. Сакулина (род. 1868) и Н. Ф. Бельчикова (род. 1890), придерживавшихся при публикации, 
в отличие от Д30, принципа точного воспроизведения как пунктуации, так и орфографии подлинника $(1931,6)$, эта «непривычность» старой графики приводит изредка к появлению ошибок в правильно расшифрованном исследователями тексте на стадии набора и корректуры. Приведем только несколько примеров подобных графических «потерь»:

$$
\text { 1) «подъ залогъ» (С. 27) / «под залогъ» (С. 11) }
$$

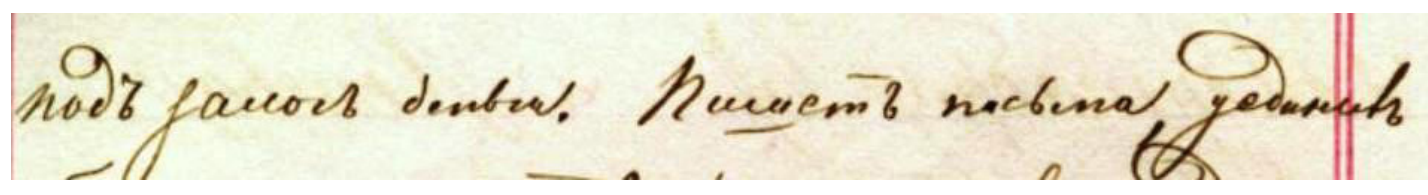

буржуазна. Мать взяла въ руки. Женихъ офйицеръ, дающій [л. 26] под залогъ деньги. Пишеть письма, уединиль себя оть семейства, (груши

2) «/передъ/ женитьб[rъ]/ой/» (С. 48) / «перед женитьбой» (С. 19)

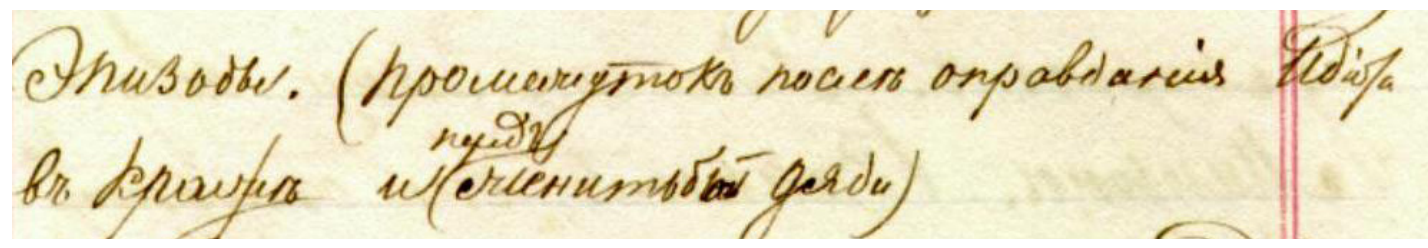

зоды. (Промежутокъ посл各 оправданія Идіота въ кражго и перед женитьбой дяди).

3) «Но Сынъ производитъ» (С. 54) / «Но С ын производитъ» (С. 21)

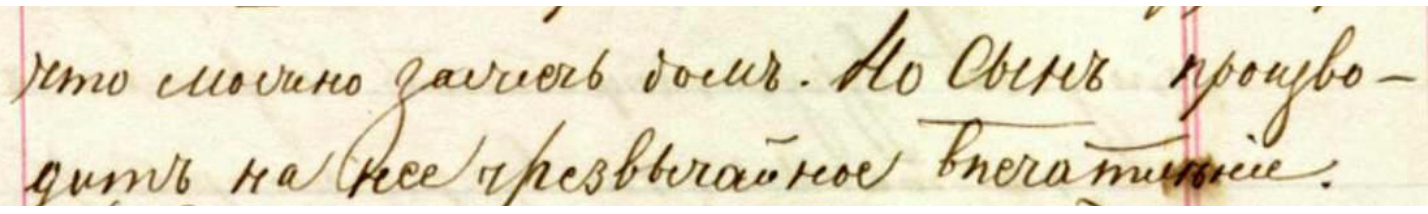

ср еды. Она понимаетъ, н. прим. что можно зажечь домъ. Но С ын производить на нее чрезвычайное впечатлґиніе.

4) «съ принижениіемъ» (С. 25)

мается съ принижениіемъ, но приличен'ъ

5) «чтобъ онъ помогъ.» (С. 80) / «чтобъ онъ помог.» (С. 26)

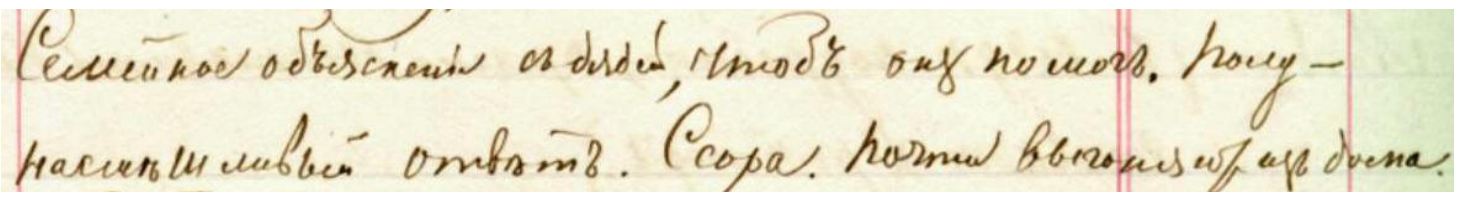


хтобъ онъ помог. Полунасмбшливый отвбтть. Ссора. Почти выгоняютъ лизь дома.

6) «въ нервномъ припадкп» (С. 81) / «въ нервномъ припадке» (С. 26)

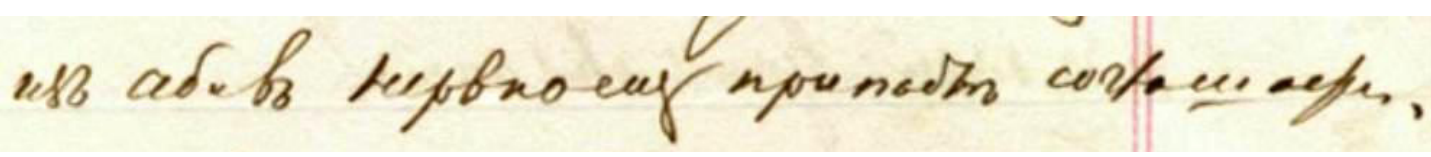

за то qто отказала Сенатору. Полтора миліона. Плдъ обепакть. Геро выведенная пзъ себл въ нервномъ припадке соглашается.

В большинстве случаев, как видим, подобное связано с концами строк, которые обычно хуже «просматриваются» наборщиком, чем середина текста, и может быть расценено как опечатка. (Забегая вперед, можно сказать, что при воспроизведении набросков к тому же роману «Идиот» из следующей тетради (РГАЛИ. Ф. 212.1.6) подобных ошибок, помимо других неточных прочтений, появляется уже значительно больше - до шести на одну страницу.)

При второй публикации записной тетради в академическом Полном собрании сочинений Ф. М. Достоевского принцип передачи текстов был другим - графика, орфография и пунктуация оригинала не воспроизводились, все было приведено в соответствие с нормами и правилами современного на тот момент русского языка. При этом ошибки прочтения, связанные именно с особенностями дореволюционной орфографии, сохранились. Приведем несколько примеров:

Неразличение «Ђ» в глаголах и глагольных формах. На стр. 23 читаем:

«- Эта страсть не любовь, а страсть удовлетвореннаго тщеславія. Когда-же дюйствительно онъ почувствоваль и увидюль <В ДЗо: увидал - 9, 161> любовь, то отказывается и отсылаеть Геро тотчасъ къ брату».

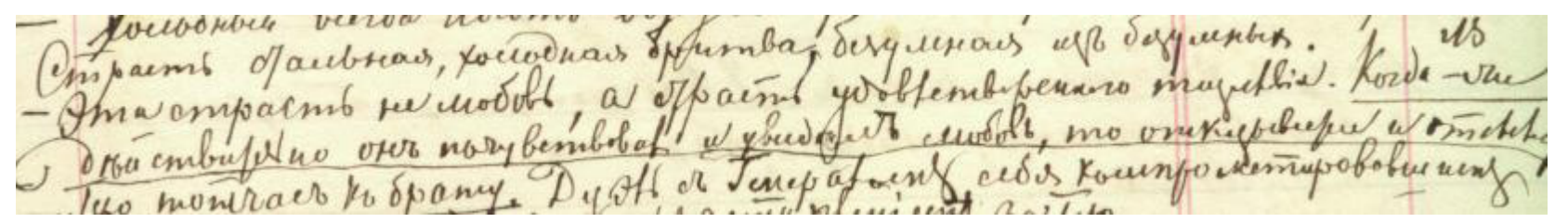

Несмотря на то, что перед нами текст, написанный довольно четким, хотя и убористым почерком, возникло неверное прочтение глагола «увидълъ». В данном примере букву «Ђ» закрывает буква «у» с предыдущей строки, но, тем не менее, запись прочитывается - перед нами другое написание буквы «Ђ», тоже характерное для почерка Достоевского, похожее на написание твердого знака:

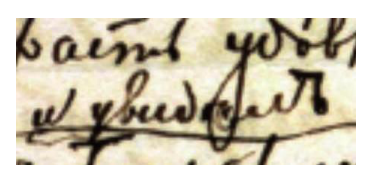


На стр. 106 неправильное прочтение двух букв меняет видовую форму глагола (появляется совершенный вид вместо несовершенного):

«- Это вы хорошо сказали, маменька, замптила Дуня.

- Стало быть я во всемъ виновать - обижался <В Д30: обиделся 7, 178> Лужинъ».

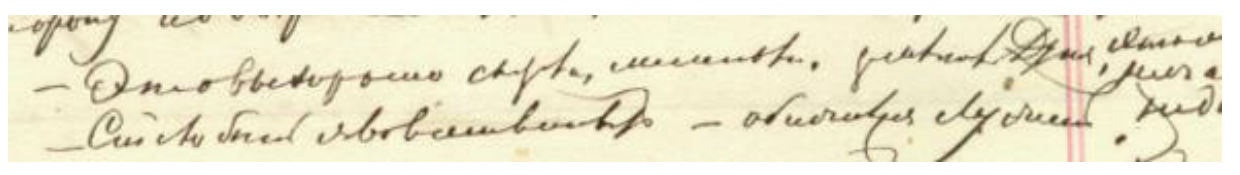

Начало написания буквы «ж» у Достоевского, действительно, иногда можно спутать с написанием буквы «д», однако в глаголе «обидюлся» в суффиксе писалась буква «Ђ», которая не прочитывается в рукописи, что и свидетельствует об ошибке Дзо.

Ошибки неизбежны при прочтении записей с полей страницы, выполненных менее четким почерком, чем основной текст. Например, на стр. 64 на полях слева читаем:

«Власти. А власть не соблазнила-бы васъ. Спкъ бы головы <В Д30: Сам би<лся> - 7, 163>. А справедливость? Да впдь это невозможное дюло.

Такъ весь земной шарв устроенъ. Матерія и духъ, должно быть равенство, изг этого жизнь».

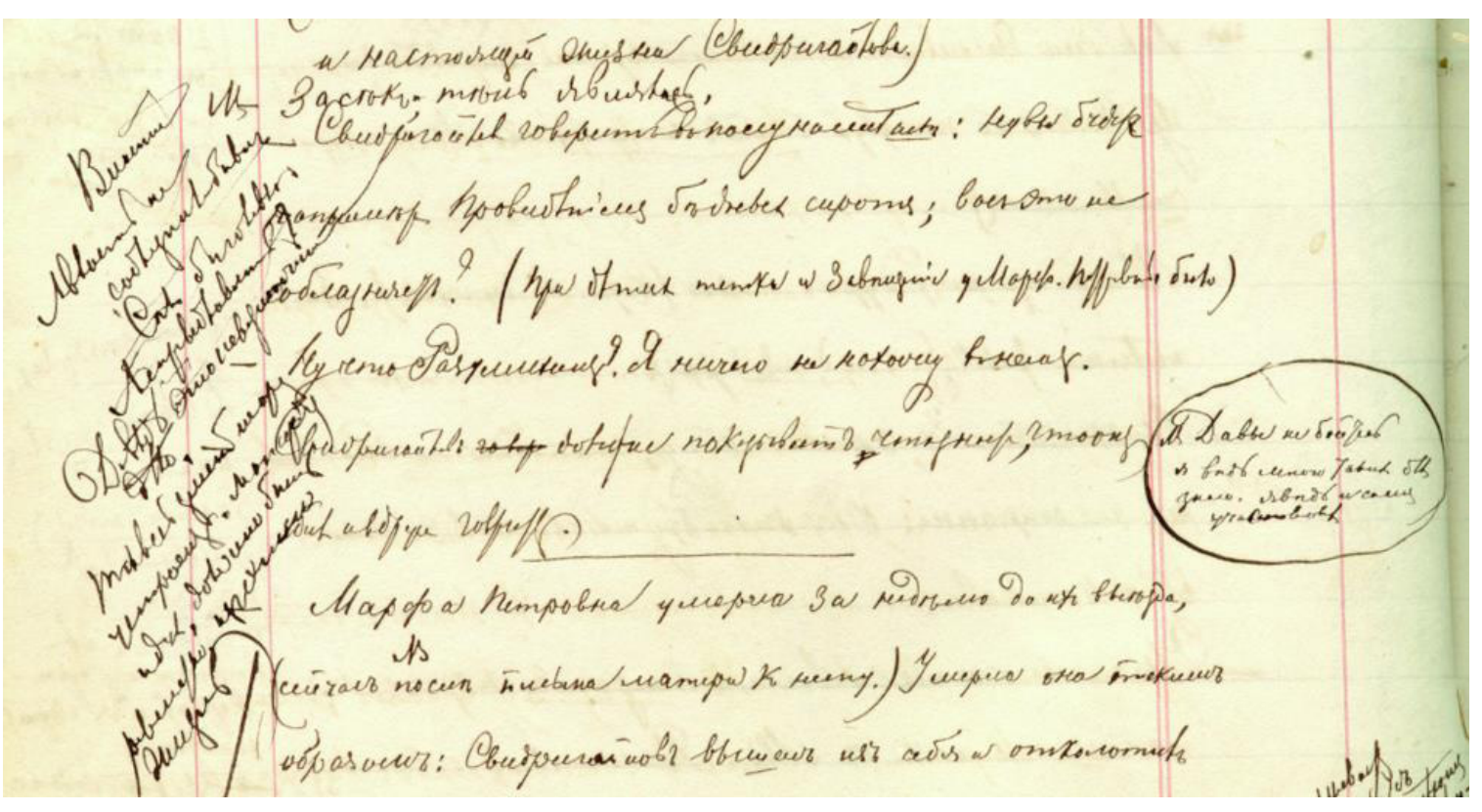

Слово «Сюкъ» нельзя прочитать как «Сам», потому что, во-первых, в корне явно прочитывается «Ђ», во-вторых, букву «м» Достоевский прописывает традиционно: см. ниже слово «Матерія» или в основном тексте: «Марфа Петровна умерла...», - а такое высокое написание, как видим в рукописи на конце слова, характерно у него для букв: «Ђ» (в одном из ее вариантов; но в данном случае вторая «Ђ» подряд в слове исключена), «л», «К» и «В» (но в последней все-таки обычно четко прописывается верхняя петля). 


\section{«Невзначайные случаи» \\ (Тире иди росчерк? Неразобранный почерк и проч.)}

Можно условно выделить в особую группу ошибки прочтения, связанные с неточно разобранным почерком, неверной трактовкой графического рисунка рукописного текста. Прежде всего это касается сложно читающейся скорописи, особенно вписок мелким быстрым почерком между строк и на полях, часто недописанных слов и отрывочных фраз. Но иногда подобное встречается и при публикации отрывков, написанных очень четким, каллиграфическим почерком, что уже можно объяснить невнимательностью либо фразеологической инерцией (когда прочитанное начало слова или первая часть словосочетания влечет за собой неверное «угадывание» дальнейшего и замену в результате текста из рукописи - на наиболее частотную, общеупотребительную, часто нейтральную словоформу, либо более распространенное сочетание слов).

Например, в наброске на стр. 14 есть ошибочное прочтение в лаконичной первоначальной характеристике одного из персонажей, жениха:

«Обличаеть что женихъ, котораго ему предпочли, [на] (молоканб) $<$ В Д30: молокосос - 7, 158> намтренъ предать ее начальнику. Жена Старщаго сына (въ нигилистки)».

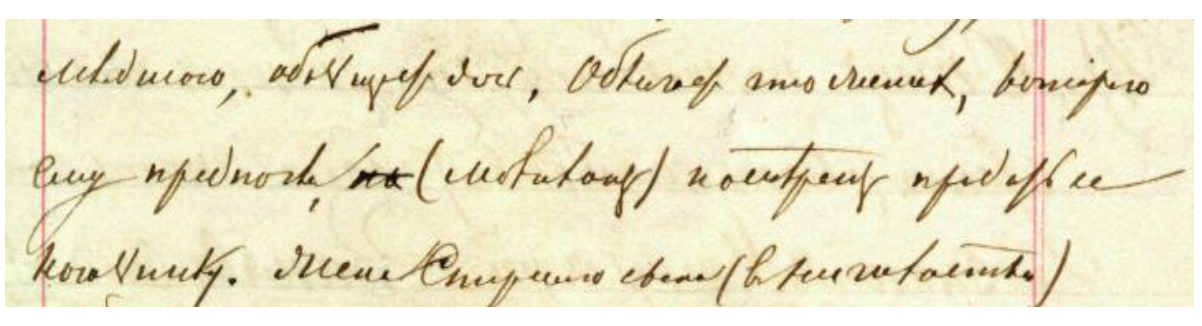

В Д30 появляется отсутствующий в рукописи лишний слог; написание же букв «о» и «а» у Достоевского иногда практически не отличается. Молокане - религиозная секта в России, члены которой отвергали церковную иерархию, иконы, мощи, монашество, гражданскую власть и военную службу, т. е. всякое пролитие крови, почему не употребляли в пищу мяса, а только яйца и молоко

Похожий случай с добавлением лишнего слога видим на стр. 24, где вместо менее частотного «не побрезгал» прочитано более употребительное сейчас «не побрезговал», хотя усеченная форма зафиксирована и в словаре В. И. Даля ${ }^{5}$, и в современных словаря ${ }^{6}$ :

"Дядя узнавъ о поступкп Сына признаеть его и завпшаеть (просить) е[го]/му/ жениться на Геро. Тоть берется. Идіоть удивляется, что тоть не побрезгаль <В Д30: не побрезговал - 9, 162>».

Возможно также, что в данном случае слово было расценено как недописанное, и конечная «л» была принята за похожую иногда на нее по написанию «в». 


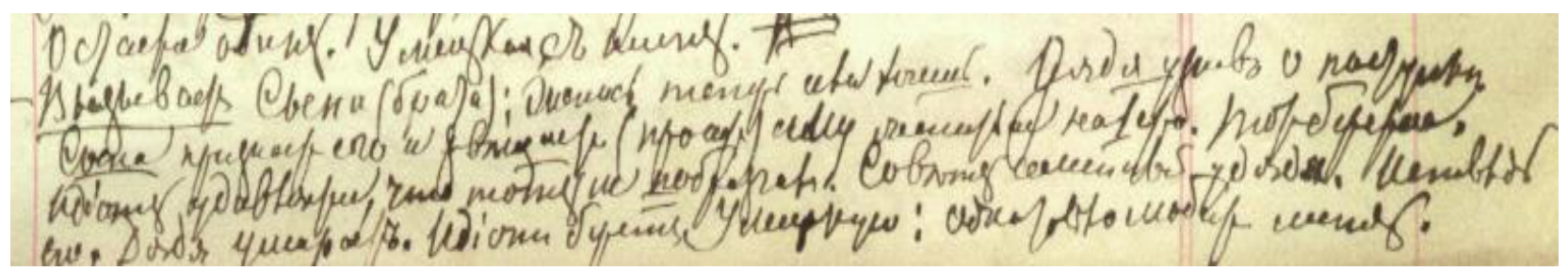

На стр. 107 в Д30 вместо четко читающегося в рукописи глагола «переговорили» автоматически набрано более нейтральное по форме и чаще встречающееся слово «поговорили»:

«/Зосимовъ при<шель>/ Мы ни о чемь не переговорили <В Д30: поговорити - 7, 179> Родя. Мнп такъ много хотпь глось> сказать».

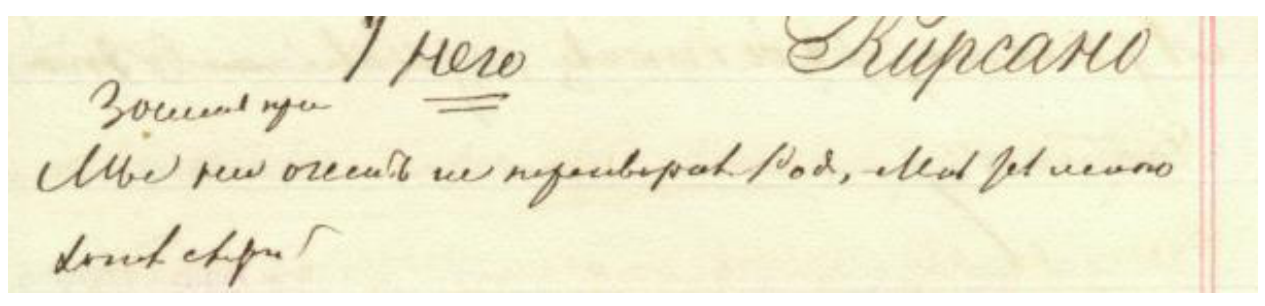

На стр. 116 в Д30 появляется еще одна очевидная ошибка прочтения глагола:

«Онъ и провель <В Д30: привел - 7, 186> меня для того, чтобъ безмолвную очную ставку сдюлать».

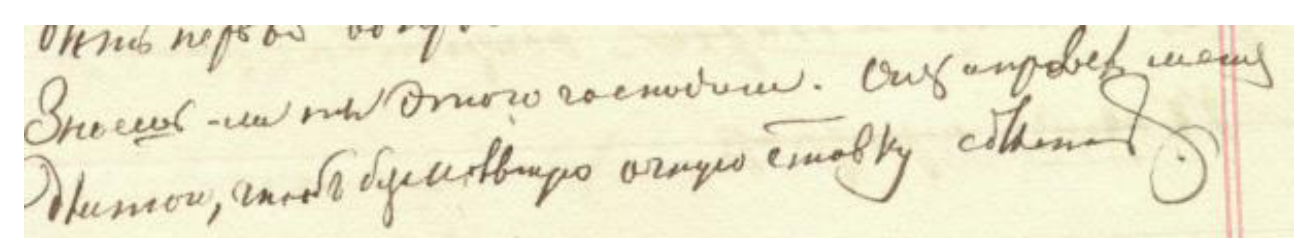

Похожая ошибка чтения возникла на стр. 25, но только в публикации П. Н. Сакулина и Н. Ф. Бельчикова - вместо «выказалъ характеръ» прочитано «высказаль характеръ» (в Д30 исправлено - 9, 162):

«Генераль разсказаль исторію о братю. $($ На станціи. Сигарык.>) Съ своей точки зргнія. И передаль характерв и выказаль <В 1931: высказаль - 34> характеръ».

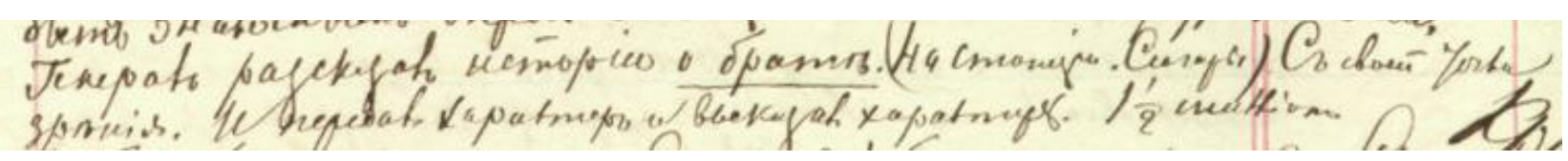

На этой же странице глагол «Признали» ошибочно прочитан и в публикации П. Н. Сакулина и Н. Ф. Бельчикова и в Д30 как существительное:

«- Вагонъ. Генераль, семья, (невпста или молодая жена) Красавица. -

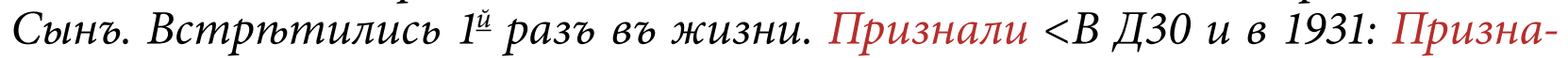
ние - 9, 162; 34>». 


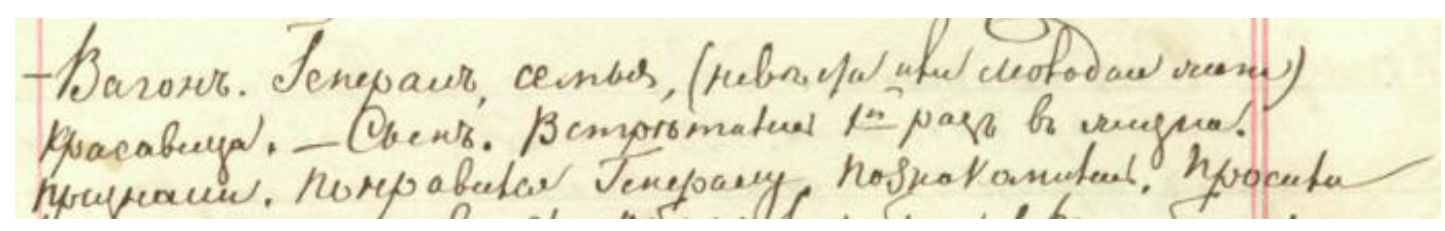

В данном случае нет характерной для буквы «і» точки, которую Достоевский чаще всего прописывает - см. фото предыдущей страницы, либо написание этого слова в черновом автографе и в черновых набросках к «Братьям Карамазовым» («я сдплаль вамъ это признаніе»- НИОР РГБ. Ф. 93.I.2.1/13. Л. 1; «Признаніе денегъ» — РО ИРЛИ. Ф. 100. № 2944429446/27. Л. 1):

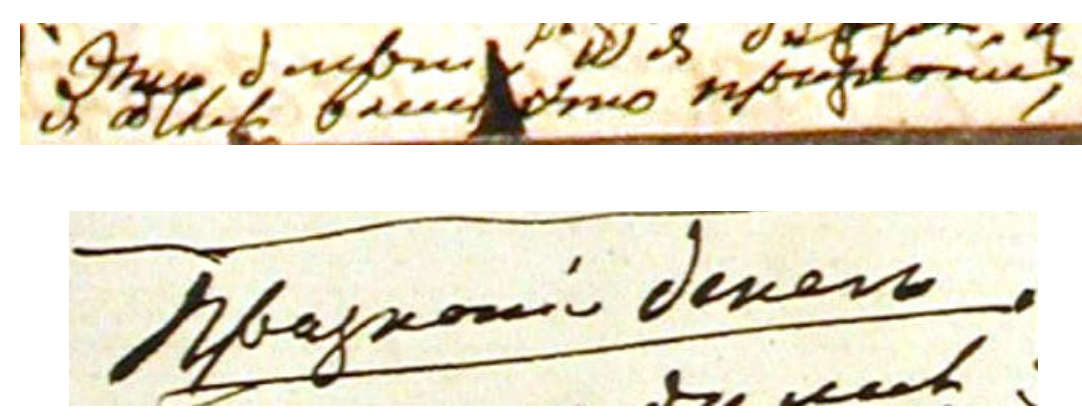

На стр. 37 мы видим пример неправильного прочтения коротких слов, в данном случае предлога «меж/между» (ошибка возникла сначала в публикации П. Н. Сакулина и Н. Ф. Бельчикова, затем перешла в Д30):

«Межь <В Д30 и в 1931: Между - 9, 144; 15> тюмь неожиданно прибыль Отеиъ семейства, рябой, брыластыци, бабистый».

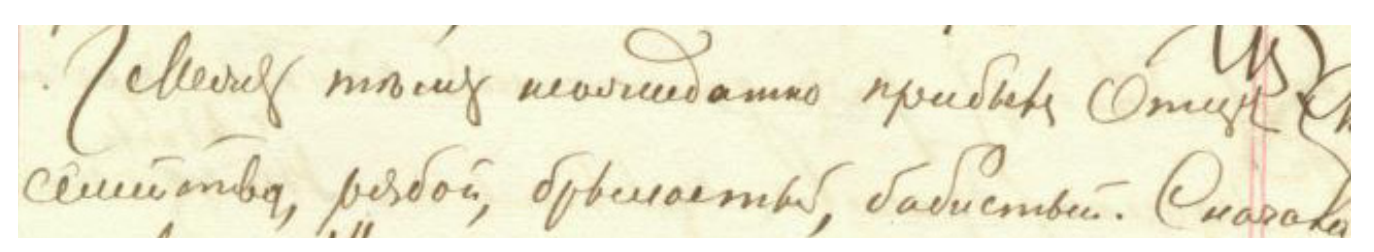

Очевидно одинаковое написание оконцовок двух рядом стоящих слов: «межъ» и «тюмъ»; такое написание буквы «ъ» также было характерно для почерка Достоевского.

На стр. 14, в уже рассмотренном выше отрывке, встречаем еще одну ошибку чтения в Д30:

«...хочеть жениться на 16 пютн. богат<ой>. Съ отияомъ дпло импетв $/ \partial y$ эль объясненій <В Д30: дуэль, объяснения - 7, 158>/».

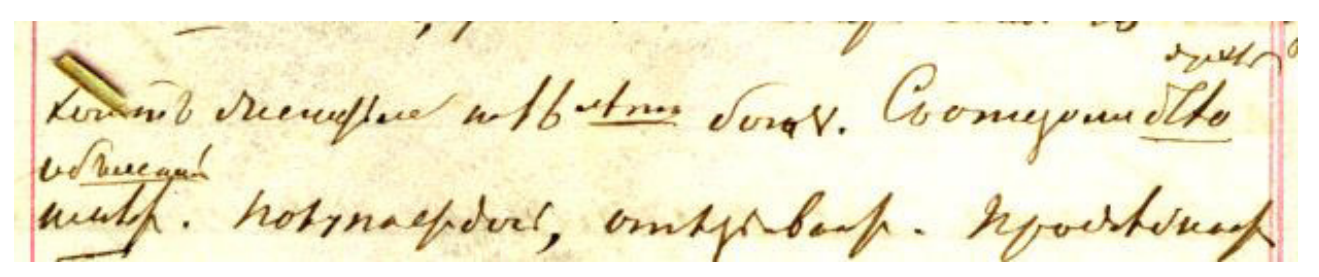


Текст вписан более мелким почерком над строкой с основным текстом, что, вероятно, и вызвало неточное прочтение. Однако конечная «й» видна довольно четко: написание буквы уходит наверх; и запятая, поставленная в Д30, в рукописи также отсутствует.

На стр. 63 встречаем неверное прочтение предлога («на» вместо «по»):

"- Насильничаніе явилось внезапно какъ мысль; а сомолся онъ съ Авд<отьей> Романовной совспмъ по <В Д30: на - 7, 162> другой идеп».

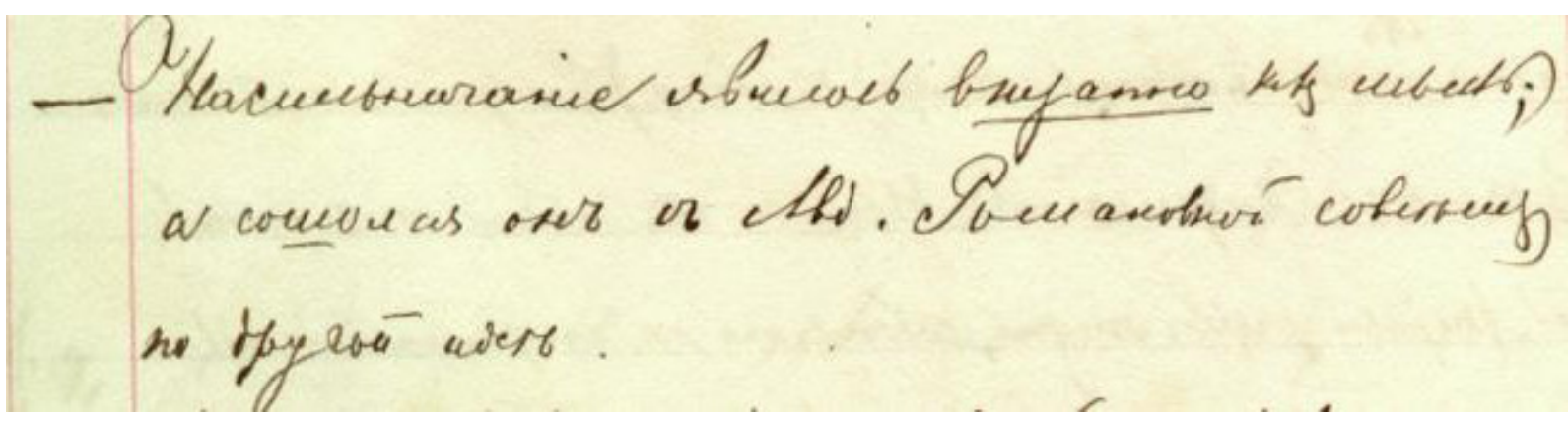

Глагол «сойтись» в переносном значении «оказаться единодушным в каком-нибудь отношении, подходящим друг для друга, согласиться в чем-нибудь» действительно обычно управляет: при предложном управлении - существительными в предложном и творительном падежах (с предлогами «в», «на» и «с»; сойтись на чем-либо, в чем-либо, с кем-либо), либо, при беспредложном управлении, - существительным в творительном падеже (сойтись чем? - характерами). Однако в данном случае рукопись и начертание букв однозначно опровергают такое «привычное» и «правильное» прочтение.

Выше мы указывали на частую путаницу в прочтении букв «о» и «а». На стр. 52 встречаем другую не менее частотную ошибку чтения: неразличение букв «и»/«а» (в Д30 исправлено - 9, 151): deนu».

«Они не нашлись <В 1931: Она не нашлась - 20> и слово осталось за дя-

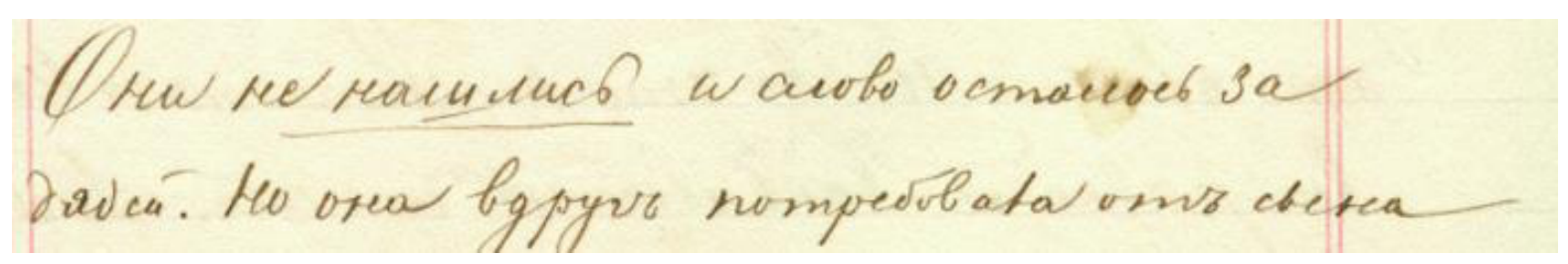

На стр. 64 также неверно прочитана запись с полей справа:

«NB. Разсказываетъ комически и съ ииническимъ смпхомғ какъ поколотиль. Физическая подробность <В Дзо: Физические подробности 7, 163> - взяль за носъ, ущипнулб». 


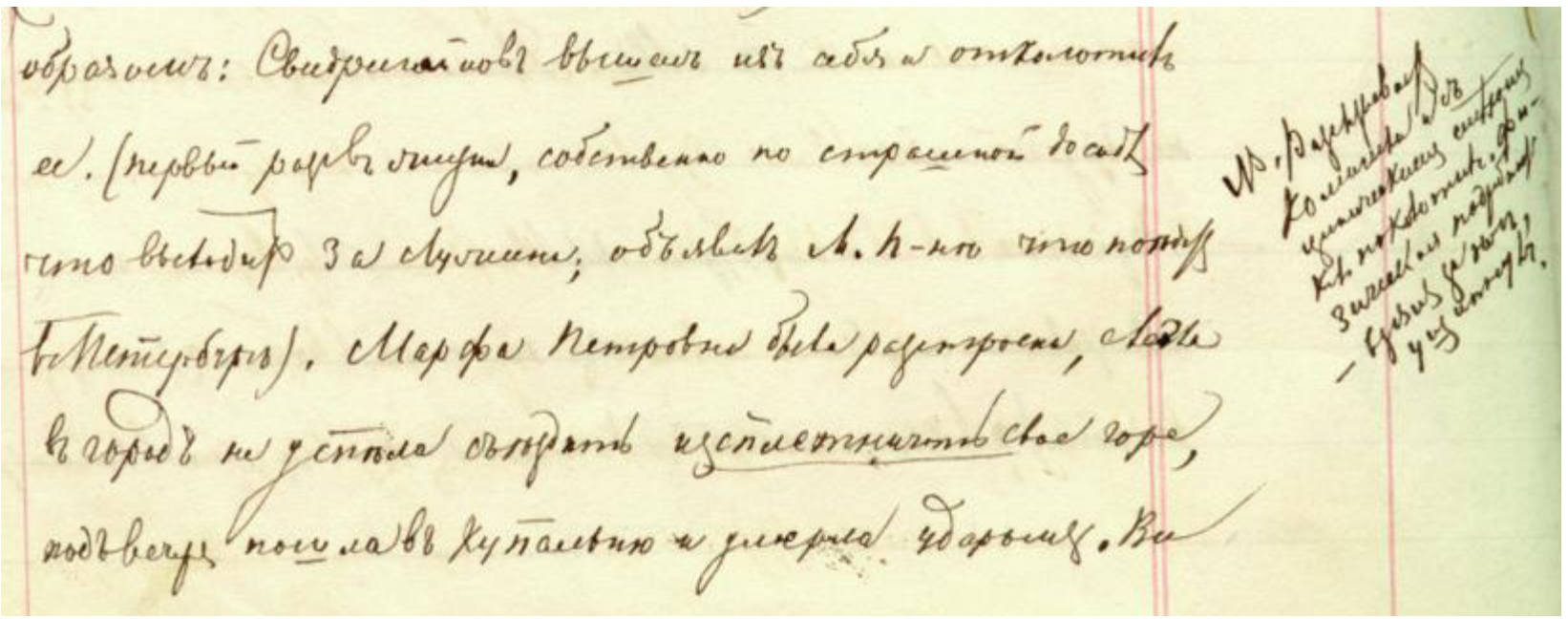

В данном примере нет традиционного для почерка писателя написания буквы «і» в окончании прилагательного.

На стр. 112 запись с полей слева также прочитана неверно:

«- Вчерашніе промахи надо поправить.

Сегодня у Порфир<ія> я прикинулся болтуномъ<.>

Невзначайные случаи <В Д30: Невзначай, и всё случай - 7, 183>».

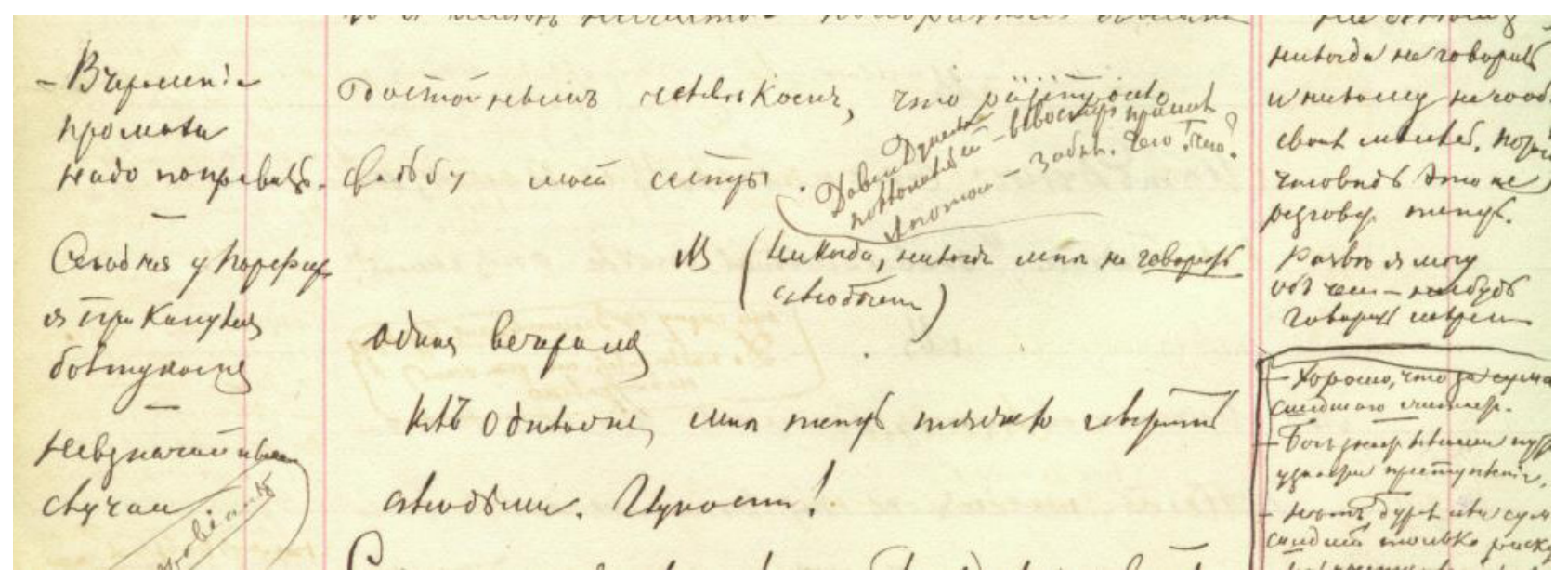

Разрыв (после буквы «й») при написания прилагательного «невзначайHble», а также его некоторая «сделанность» привели к домысливанию фразы и ошибке.

На стр. 120 под заголовком «Капитальное» дан спор Раскольникова с Соней:

«- Она вошь. - Ниоть не вошь. /А коли вошь почему вы такъ мучаетесь<.>/ — Ну такъ арифметическ<и> <В Д30: арифметика - 7, 188>, кто больше потянеть». 


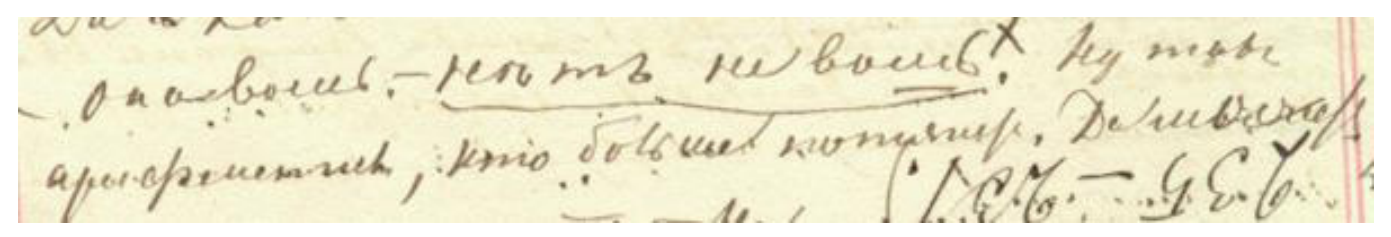

При скорописи Достоевский часто недописывал окончания слов, но сочетание «ск» в слове «арифметически» узнаваемо. Буква «и» действительно не дописана, мы восстанавливаем ее в редакторских скобках.

Некоторые ошибки чтения приводят к изменению смысла записи. Так, на стр. 68 читаем:

«Внезапное движеніе Сони, подошла къ нему<:> Зачпмъ вы это сдплали. Слезы. Я люблю тебя - гордый <В Д30: горячий - 7, 166> разговоръ».

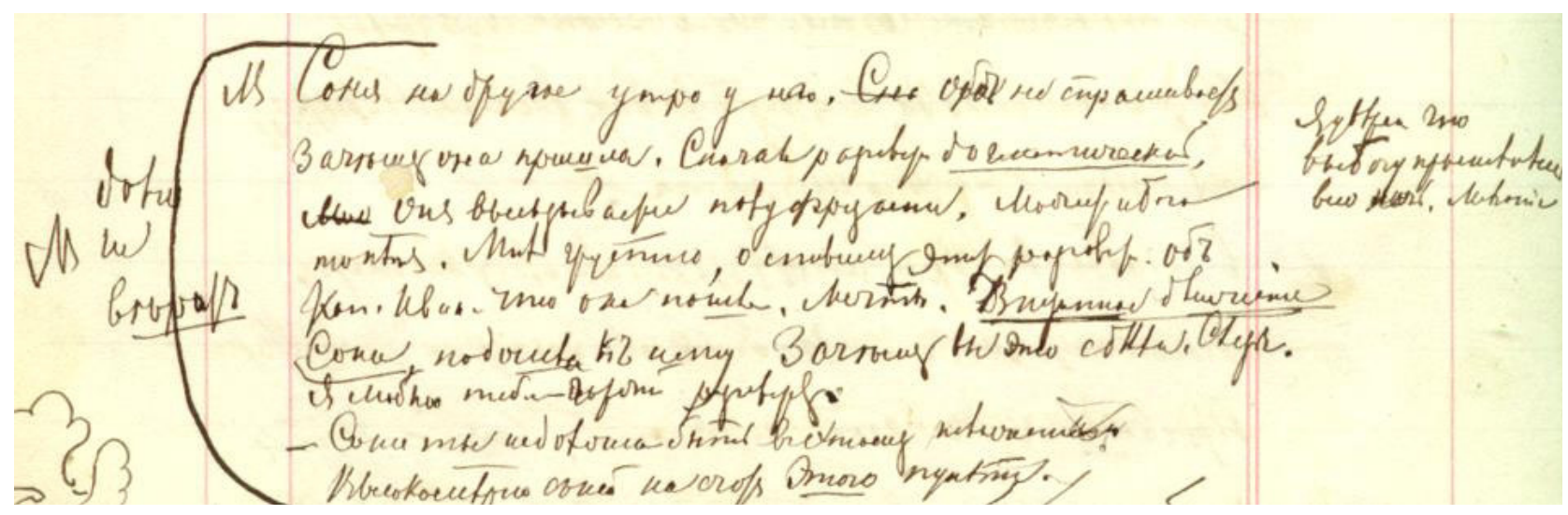

Букву «Д» Достоевский часто не прописывает до конца, как в данном случае (ср., например, выше прописанную «д» в слове «движеніе»). Но в окончании прилагательного нет буквы «і», чтобы его можно было прочесть как «горячий». Более того, разговор между Соней и Раскольниковым действительно «гордый»: выше говорится о том, что разговор принял сначала форму «догматического», Раскольников разговаривает как бы нехотя, «полуфразами», как будто произносит мысли вслух («Можетъ и Бога то нпть»). Финальная характеристика в этом блоке записей: «Высокомпрно съ ней на счоть этого пункта». На полях слева и справа имеются записи: одна (справа) - гордые, высокомерные, почти насмешливые слова пока еще не раскаявшегося главного героя («Я увпренъ что вы Богу промолились всю ночь»). Другая (слева) - помета Достоевского, характеризующая «переходное» состояние Раскольникова («NB долго не впритъ»).

Иногда ошибки возникают при смысловом делении фразы, как, например, на стр. 82:

«Геро пробуеть съ нимь то смпяться, то въ изступленіи и бпшенствп кричать. Что она никогда не будеть его женой въ сущностик.> Онъ согласенъ <В ДЗо и в 1931: Что она никогда не будет его женой, - в сущности, он согласен - 9, 156; 27>». 


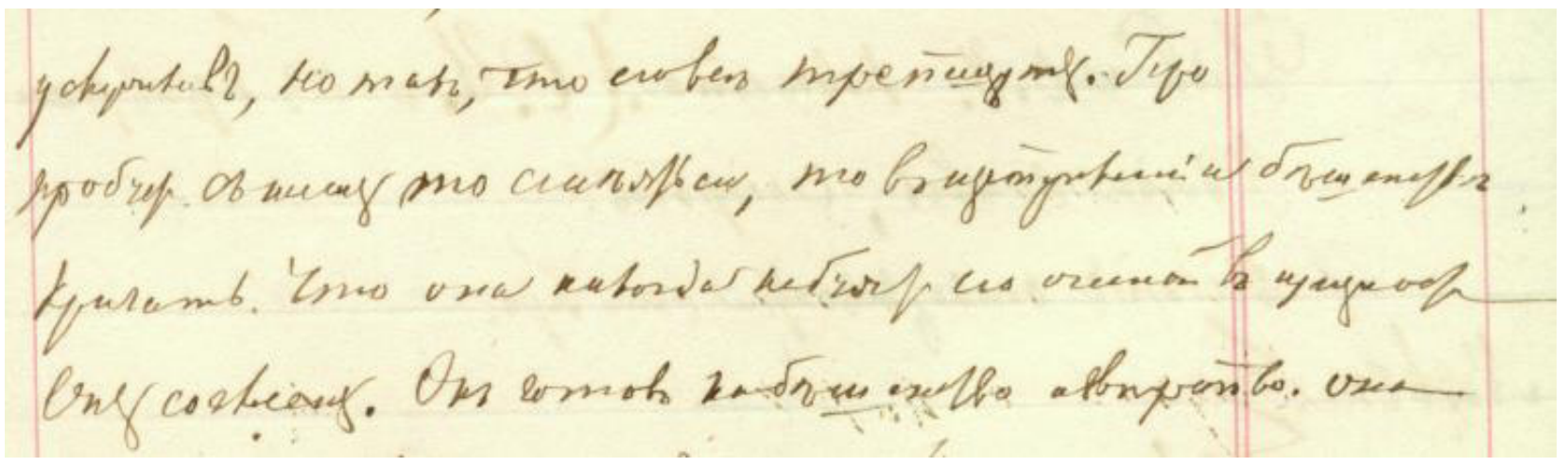

Очевидно, что сочетание «въ сущзности» относится к предложению «Что она никогда не будетъ его женой...». Далее начинается новое предложение - местоимение «Онъ» написано с заглавной буквы. Тире, которое появилось в публикациях П. Н. Сакулина и Н. Ф. Бельчикова, а также в Д30, на самом деле является росчерком пера.

На стр. 106 снова ошибка чтения меняет смысл предложения:

«въ тоскп онъ пришоль какъ-то къ матери, когда Дуни не было, иаловаль ей ноги, плакаль, рыдаль и ушоль <В ДЗ: умолял - 7, 178> ничего не объяснивщи».

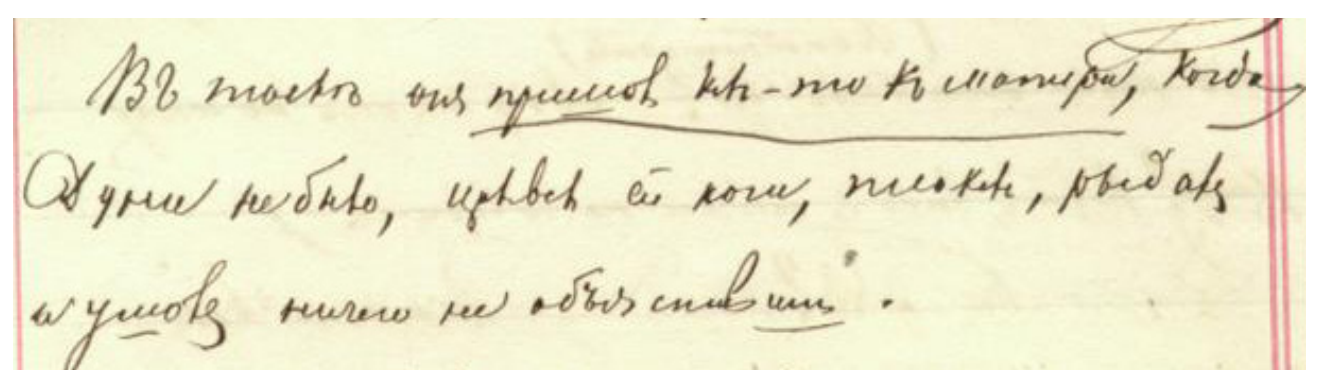

В слове «ушолъ» присутствует характерное для почерка Достоевского нижнее подчеркивание буквы «ш» (см. выше в этом же предложении слово «nришолъ»). Перед нами краткая характеристика героя, который в порыве отчаяния приходит к матери, но ничего не может ей рассказать и, так и не объяснившись, уходит.

На стр. 121 в Д30 наблюдаем домысливание слова из вставки, которое не удалось прочесть:

«Всь великіе люди были счастливы. /Ихъ грусть счастье <В Д30: переживанья - 7, 189>, ихъ страдан<ья> счастье<.>/ Они должны были быть счастливы».

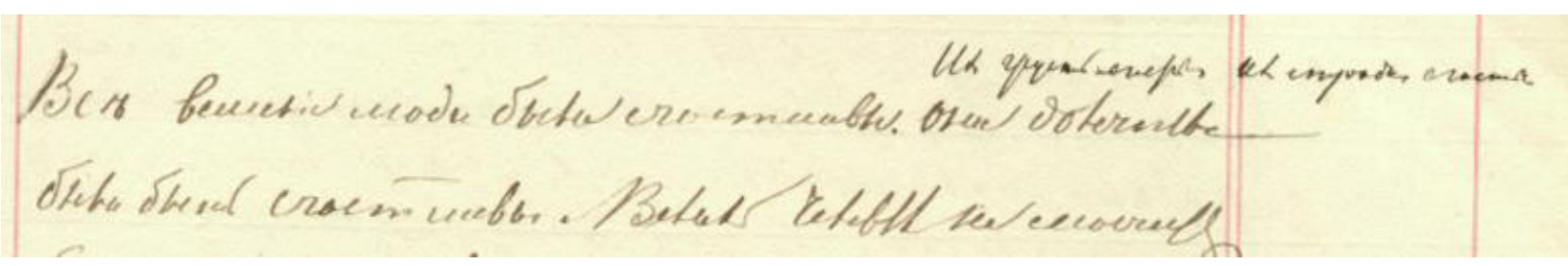


В данном примере слово «счастье» является частью составного именного сказуемого, а вместо опущенного глагола-связки в двух параллельных конструкциях по современным правилам должно было бы стоять тире: «Их грусть - счастье, их страдан<ья> - счастье».

На стр. 143 неверно «угаданное» слово обессмыливает всю фразу:

«Свидригайловъ и Дуня (сиена насилія)<.> Неудалось. Ночь въ развратпь. На другой день застрглился. Контрасты. Описаніе гемороидальн<ыхъ> Петербургск<ихъ > припадковъ <В Д30: притонов - 7, 202> (поэтичнпе)».

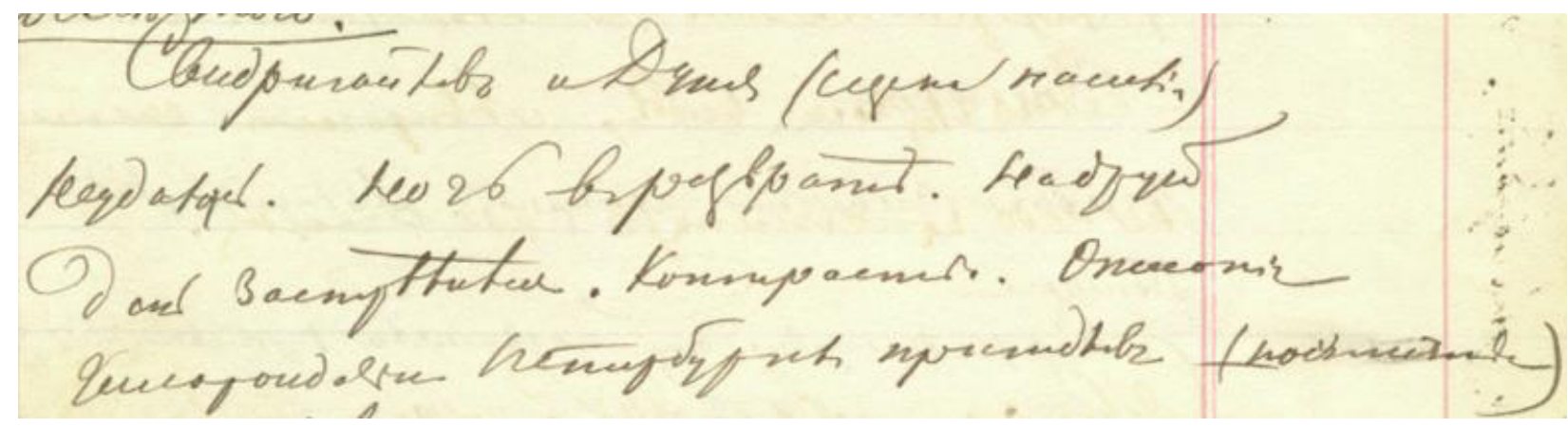

В данном примере «фразеологическая инерция» домысливания словосочетания (петербургские при...тоны) привела к появлению слова, совершенно не читающегося в рукописи: после приставки тут четко прописано сочетание «падк» с тремя высокими буквами («д», «К», «в»), нисколько не напоминающими по очертаниям заявленное сочетание «тон».

На стр. 144, где речь идет о Свидригайлове и его страстных, болезненных наклонностях, Достоевский в приписке сверху передает детскую речь, в Д30 она нивелирована:

«Марфа Петровна ему позволяла крппостныхъ, только чтобы онъ сказывался. Воть только насчеть Дунечки возмутилась./

/длястюйте балинь!'/ <В ДЗО: для спокойствия божия - 7, 202>

NB Если это Богъ сочиниль, то это великій человпкъ!».

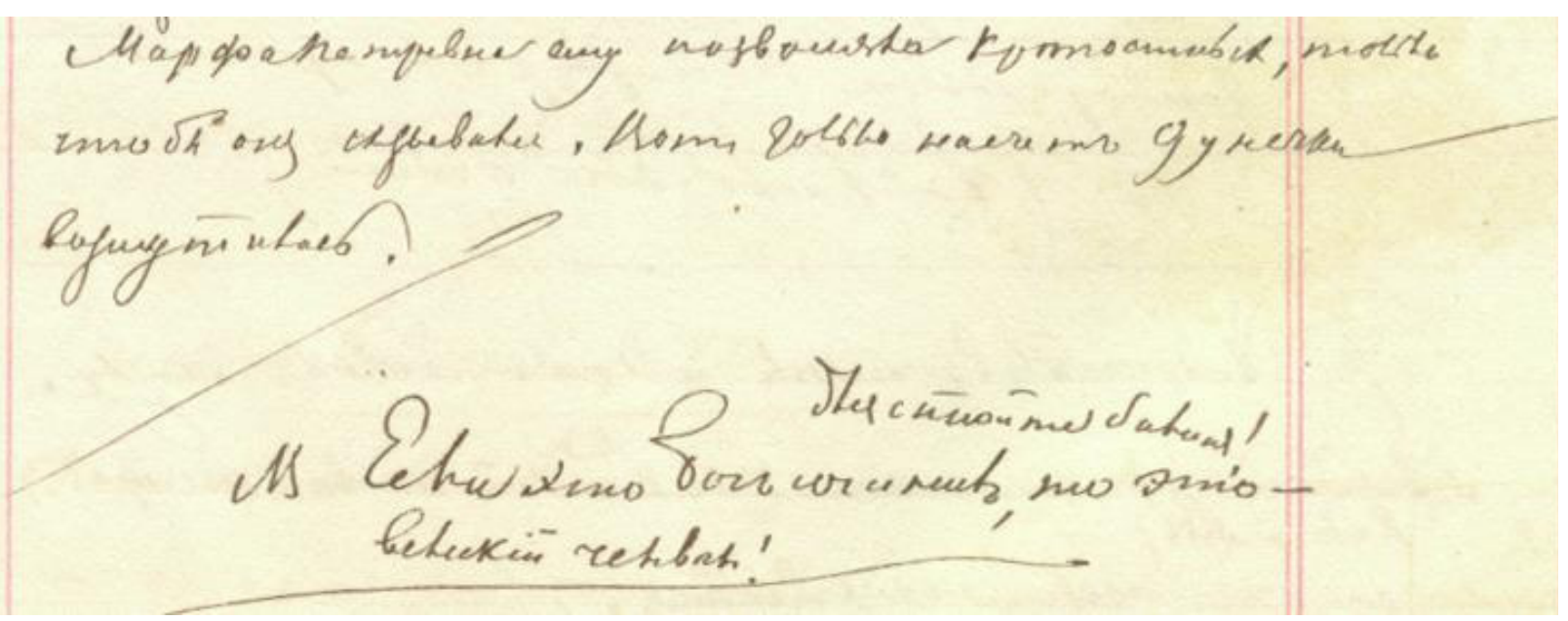


В данной фразе не читаются слова «спокойствия» и «Божия». В первом случае в середине слова не прочитываются необходимые буквы, среди них - высокая «в», кроме того - все слово короче по длине, чем было бы нужно. Во втором случае явная высокая «л» в середине слова никак не может быть прочитана как «ж»; отсутствует «и десятеричное», а первая «б», написанная тут как строчная, также опровергает подобное прочтение: у Достоевского слово «Божія» писалось только с заглавной буквы. Один из вариантов начертания писателем прописной «Б» виден на этой же странице чуть ниже (слово «Богъ»), либо в следующей записной тетради (РГАЛИ. Ф. 212.1.6. С. 130) среди набросков к «Идиоту» («...Я тебя вмпсто Бога почитаю...»):

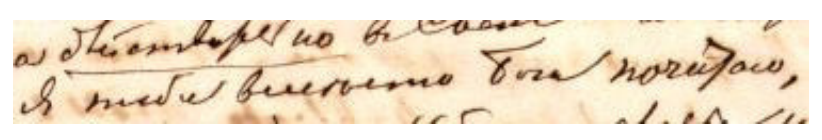

На стр. 150 неверно прочитан глагол, в написании которого явно присутствует буква "р» с характерной нижней петлей, а за ней - тоже характерно высокая в начале буква «ы», а не сочетание «ст»; в суффиксе не прочитывается буква «Ђ», которая там необходима («проистлъваемся» - от «истльть»):

«Разумпет<ся> теперь мы проигрываемся <В Дзо: проистлеваемся 7, 204>, не стпосняемся обязанностями, насъ бьють по рожг и мы прячемся, исподлились - впдь это свободнпе. Нигилизмъ въ своемъ родю».

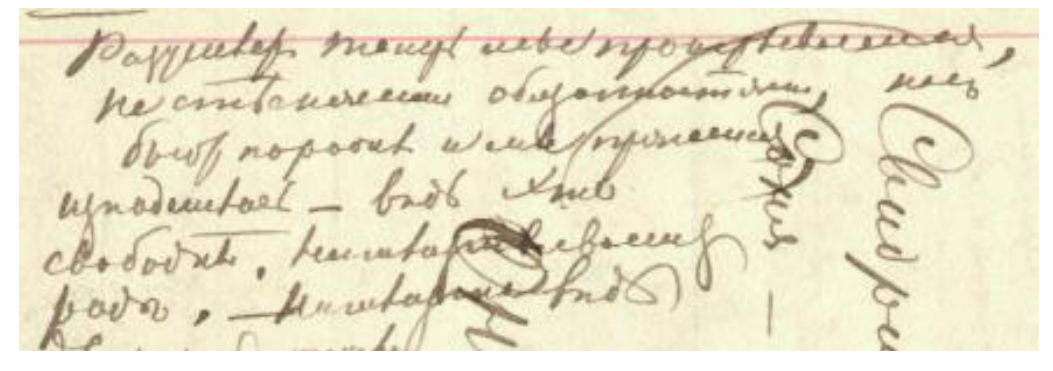

Встречаются также явные опечатки набора, не замеченные в корректуpe, например:

«Часть, петербургская сторона, мпдная каска, Ахиллессъ <В Дзо: Ахеллес - 7, 189>» (cmp. 122).

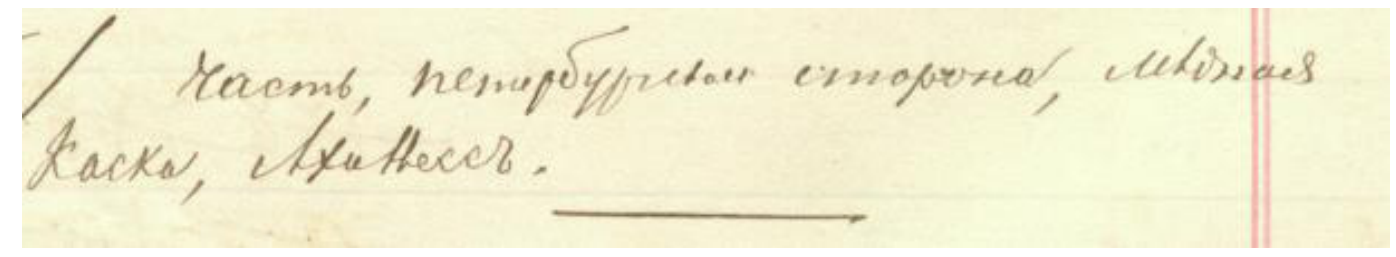




\section{«Растленный» или «распаленный»?}

На той же стр. 14 рукописи встречаем более интересные и сложные случаи написаний, при расшифровке которых возникли разночтения с Д30:

«Младшій сынъ, распаленныцич?> Свидр<игайловымъ> <В Д30: растленньий Свидригайлов - 7, 158>. Свид<ригайлову $>$ 4[0]/5/ лють...».

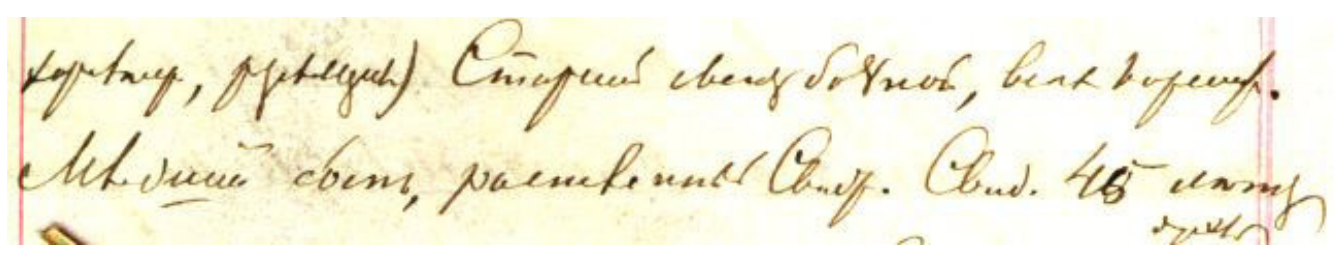

И, чуть ниже:

«В (Распаленному <В Д30: Растленному - 7, 158> молодому человпку карьеру. Сочинить)».

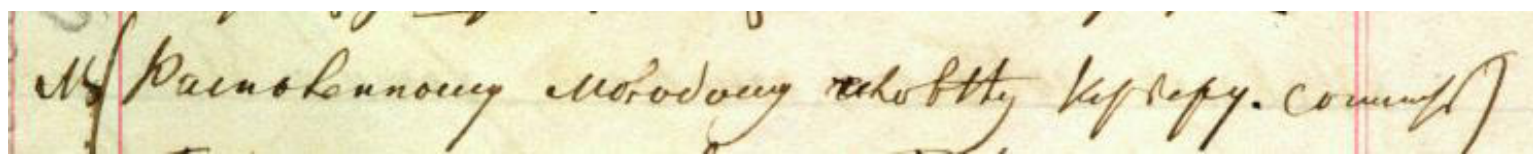

Для лучшего понимания приведем набросок сюжета с данной страницы полностью (спорные слова выделены цветом):

«Отецъ, Севастополецъ, [Старшій] все промоталь, слабая пенсія, дочь, два сына, брать (пьянчужка и приживальщикъ<,> характеръ, разскащзкб)<.> Старшій сынъ больной, вспхт кормитъ. Младщій сынъ, распаленныциц?> Свидр<игайловымъ>. Свид<ригайлову > 4[0]/5/ лптьь<,> хочеть

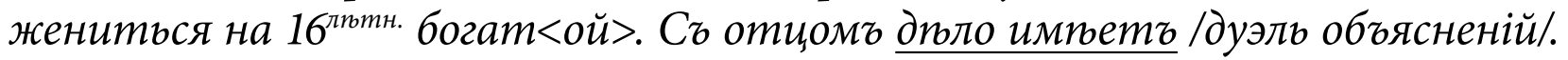
Покупаетъ дочь, отказываютъ. Продолжаетъ бъть другомъ (тоть самьии, который хотпль застрплиться. Демонб, сильнья страсти. Говоритъ.) Распекаеть /(даеть деньги)/ младшаго, обольщаеть дочь. Обличаеть что женихъ, котораго ему предпочли, [на] (молоканъ) нампренъ предать ее начальнику. Жена Старшаго сына (въ нигилистки)<.> Дочь за Свидр<игайло>ва сама идетъ. (Свид<ригайловъ> умерщвляеть своего приживальщика. Дружится съ ребенкомъ на улии,ь<.>) Переворотъ. Катастрофа. -

NB (Распаленному молодому человпку карьеру. Сочинить)<.>

[M] Кто-то изг нихъ получаеть насльдство -».

На неверную расшифровку недописанного в рукописи слова «Свидр.» указала Н. А. Тарасова. Действительно, если внимательно вчитаться в приведенный отрывок, то прочтение (в именительном падеже), предложенное Д30, окажется неточным: «Свидригайлов» и «младший сын» не могут быть одним и тем же лицом - из дальнейшего повествования следует, что именно Свидригайлов воздействует на описываемых героев, детей севастопольца-отца: 
«распекает» младшего сына («дает деньги»), «обольщает дочь», которая позже «сама идет» за него. Стало быть, в данном случае подразумевается использование фамилии в косвенном падеже: «Младший сын, распаленный<?> Свидр<игайловым>».

Сложнее с эпитетом, который писатель дал в этом наброске младшему сыну. Во втором случае графика совершенно точно подтверждает, что прочтение Д30 («Растленному») неверно - буква «т» после приставки в рукописи не читается, зато хорошо видно четко выписанное «па»: «Распаленномy <Свидригайловым. - M. 3., Т. П.> молодому человюку...». В начале же эпизода (в первом примере) графика такого же бесспорного решения не дает - предполагаемая буква «а» в сочетании «па» читается очень нечетко, а в целом графический рисунок действительно больше напоминает начертание «т», чем «па». Для сопоставления и большей наглядности мы приведем написание этих слов на данной странице, а также примеры из нескольких других рукописей Достоевского в виде таблицы:

\begin{tabular}{|c|c|}
\hline $\begin{array}{l}\text { РГАЛИ. Ф. 212.1.5. С. } 14 \\
\text { «распаленному» }\end{array}$ & \\
\hline $\begin{array}{l}\text { РГАЛИ. Ф. 212.1.5. С. } 14 \\
\text { «распаленныцй»<?>/«растленныцй»<?> }\end{array}$ & \\
\hline $\begin{array}{l}\text { РГАЛИ. Ф. 212.1.12. С. } 139 \\
\text { «растлюнньй » }\end{array}$ & \\
\hline $\begin{array}{l}\text { РГАЛИ. Ф. 212.1.17. С. } 5 \\
\text { «растлпнное» }\end{array}$ & Pacmenowavel \\
\hline $\begin{array}{l}\text { РГАЛИ. Ф. 212.1.16. С. } 17 \\
\text { «растлиннаго» }\end{array}$ & $\operatorname{coc} 20$ \\
\hline $\begin{array}{l}\text { НИОР РГБ. Ф. 93.I.1.4. Л. } 77 \\
\text { «разстлиьнной» }\end{array}$ & rpape \\
\hline
\end{tabular}

Н. А. Тарасова считает более вероятным прочтение Д30 (с исправлением падежной формы в фамилии героя): «Младщій сынъ, растленный Свидр<игайловымъ>» - исходя из графического рисунка слова и при условии языковой вариативности (в слове «растленный» допускается написание суффикса как через «Ђ», так и через «е»", т. е. явное отсутствие «Ђ» в рукописи в первом случае употребления спорного эпитета не будет считаться достаточным аргументом против подобного прочтения). Главным аргументом, по ее мнению, тут выступает именно написание сравниваемых слов: предполагаемая буква «п» не похожа на себя; в предполагаемой 
букве «а» нет наплыва, который есть в той же букве «а» в слове «Распаленному» («молодому человику») ниже по тексту (и есть в принципе в написании круглых букв); т. е. в первом случае прочитывается сочетание «ст», а не «спа» и слово читается как «растленный».

Мы же попробуем, не снимая вопроса полностью, обосновать второе прочтение: «Младшій сынъ, распаленный<?> Свидр<игайловымъ>».

Во-первых, одним из аргументов могут явиться рукописи самого писателя. Несмотря на в принципе имеющуюся в языке вариативность написания слова «растлънный»/«растленный» и на безусловно присутствующую в языке самого Достоевского вариативность в написании некоторых слов и словосочетаний, в данном случае, после просмотра достаточно большого объема его рукописей, пока не удалось обнаружить ни одного случая написания им данного суффикса (в разных частях речи) через «е» - все встреченные нами написания были только через «Ђ».

В записной тетради 1874-1875 годов («И безъ сытости собирають (тлюнное) богатство»; “- Невоздержный и растлюнный человпкъ...»РГАЛИ. Ф. 212.1.12. С. 138, 139):

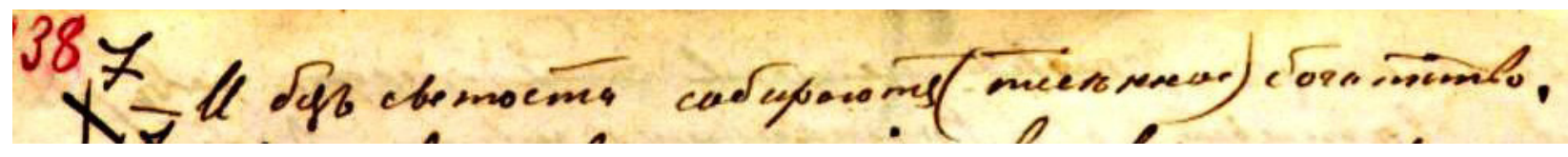

Hebepoforeaber a pacmecreseder

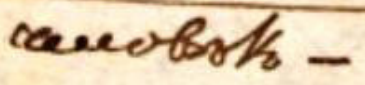

В записной тетради 1876-1877 годов («растлюннаго нашего общества съ другой сторонъь» — РГАЛИ. Ф. 212.1.16. С. 177):

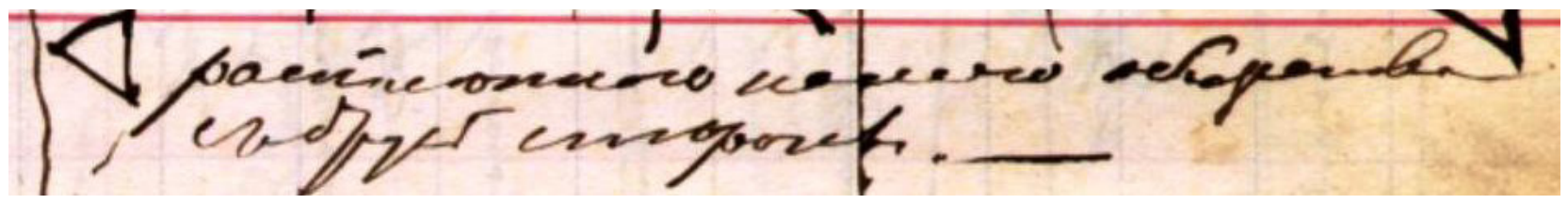

В записной тетради 1880-1881 годов («Нюмецкій мальчикъ (долгъ) и русскій (растлпнное семейство)». И здесь же: «А у насъ въ семействахъ лишь растлпніе» - РГАЛИ. Ф. 212.1.17. С. 5):
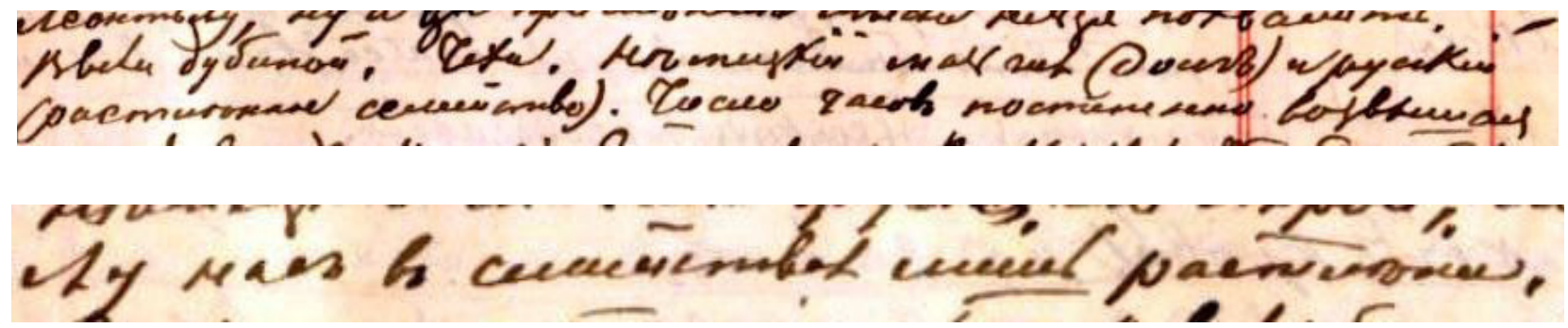
Слова «растльніе»/«разстльніе», «растльнъ»/«разтльнъ» в записных книжках и тетрадях и в просмотренных рукописных материалах к трем крупнейшим романам («Бесы», «Подросток» и «Братья Карамазовы») также везде без исключения пишутся только через «Ђ», без вариантов (РГАЛИ. Ф. 212.1.6, наброски к «Идиоту» - встречается 5 раз; РГАЛИ. Ф. 212.1.11. Л. 4: «мысль самоспасенія оть разстлинія»; РГАЛИ. Ф. 212.1.15. Л. 48 об. встречается дважды: «Растлпніе могло соскочить мгновенно. <...> Народъ будетъ такой же и также растлюнъ»; РГАЛИ. Ф. 212.1.17. С. 5 - трижды; НИОР РГБ. Ф. 93.I.1.4. Л. 64, 77, наброски к «Бесам» - дважды: «Какъ вы мелочны, разтлпны, жадны и тщеславны»; «одинъ мужъ, женатый на разстлюнной имъ»; РО ИРЛИ. Ф. 100. № 29444-29446/36. Л. 1: «раннее растльніе и прирожденный изинимъ»).

Второй аргумент, как нам кажется, - бесспорно прочитывающийся в четвертом примере эпитет «Распаленному». Весь текст на стр. 14 представляет собой цельный набросок одного из сюжетов. И в обоих случаях с помощью эпитета дается характеристика одному и тому же лицу, «младшему сыну», «молодому человеку», на которого оказывал определенное негативное влияние Свидригайлов. Причем эпитет, появившийся в самом конце наброска, внизу страницы: «NB (Распаленному молодому человпку карьеру. Сочинить)» - явно взаимосвязан с эпитетом более ранним. Это не дополнительное развитие сюжета (где появление новой характеристики уже упомянутого лица было бы уместно), а нотабене, помета автора, вдогонку, для самого себя (на что указывают также скобки) о том же самом герое, которого он уже охарактеризовал выше («распаленныци младшій сынъ») и которому нет нужды придумывать дополнительные эпитеты.

В статье были проанализированы самые существенные и частотные случаи неверного прочтения творческих записей Ф. М. Достоевского в его записной тетради (РГАЛИ. Ф. 212.1.5). Можно сделать вывод, что исследуемая тетрадь была прочитана и в 1931 году (П. Н. Сакулиным и Н. Ф. Бельчиковым), и позже в Д30 с ошибками, нередко меняющими смысл всего высказывания. В статье продемонстрированы только три группы ошибочного прочтения: пропуск творческих записей, неверная атрибуция и ошибки, связанные с незнанием дореволюционной орфографии и графики самого писателя. Их знание должно быть обязательным квалификационным требованием к текстологу, который изучает рукописи в «старой» орфографии.

\section{ПРИМЕЧАНИЯ}

* Исследование выполнено по гранту Министерства образования и науки России «Новые источниковедческие и текстологические исследования русской словесности XIX-XX вв.» (№ 34.1126).

1 См.: Из Архива Ф. М. Достоевского. Преступление и Наказание. Неизданные материалы; предисл. и ред. И. И. Гливенко. М.; Л., 1931. С. 166-217.

2 См.: Из Архива Ф. М. Достоевского. Идиот. Неизданные материалы; под ред. П. Н. Сакулина и Н. Ф. Бельчикова. М.; Л., 1931. С. 11-95. Далее: 1931. 
3 См.: Достоевский Ф. М. Полное собрание сочинений: в 30 т. Т. 7, 9, 17, 27. Л., 1973, 1974, 1976, 1984. Далее: Д30.

4 См.: Большой академический словарь русского языка; РАН, Ин-т лингвистических исследований. Т. 1-22- . М.; СПб.: Наука, 2004-2013- . Т. 10: Медяк-Мячик. М.; СПб., 2008. С. 348; Даль В. И. Толковый словарь живого великорусского языка : в 4 т. М.: Русский язык, 2007. Т. II. С. 334.

5 См.: Даль В. И. Толковый словарь живого великорусского языка. Т. І. С. 127.

6 См.: Большой академический словарь русского языка. Т. 2: Благо-Внять. М.; СПб., 2005. С. 182.

7 «Здравствуйте, барин!».

8 В.И. Даль указывает даже на разницу в значении в зависимости от наличия/отсутствия в слове буквы «ять»: «Растльванье, растленье, дъйст<віе $>$ по зн<а >ч<енію>

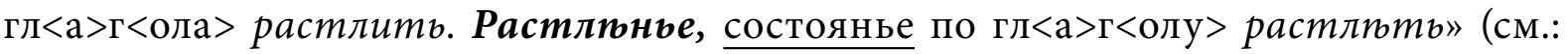
Даль В. И. Толковый словарь живого великорусского языка. T. IV. С. 78. Выделено В. И. Далем. - М. 3., Т. П.). Однако, как показывает речевая практика, в словах с подобным чередованием почти всегда происходила путаница значений, и даже в пределах текстов одного человека (писателя, например), иногда - в пределах одного листа, могли встречаться оба написания (для Ф. М. Достоевского, например, характерно чередование написаний: «копъйка»/ «копейка»).

\section{СПИСОК ЛИТЕРАТУРЫ}

1. Баршт, К. А. За строкой записной тетради... / К. А. Баршт // Нева. - 1983. - № 10. C. $196-199$.

2. Баршт, К. А. «Каллиграфия» Ф. М. Достоевского / К. А. Баршт // Новые аспекты в изучении Достоевского : сб. науч. тр. / отв. ред. В. Н. Захаров. - Петрозаводск : Изд-во ПетрГУ, 1994. - С. 101-129.

3. Баршт, К. А. Рисунки в рукописях Достоевского / К. А. Баршт. - Санкт-Петербург : Формика, 1996. - 224 с.

4. Баршт, К. А., Райхель, Б. С., Соколова, Т. С. О методе цифровой спектрофотометрии в изучении рукописи писателя (на примере «Сибирской тетради» Ф. М. Достоевского) / К. А. Баршт, Б. С. Райхель, Т. С. Соколова // Известия РАН. Серия литературы и языка. - 2012. - Т. 71. - № 4. - С. 20-44.

5. Баршт, К. А., Малафеевская, Т. Н. Дипломатическая транскрипция как текстологическая задача: три страницы из «записных тетрадей» Ф. М. Достоевского / К. А. Баршт, Т. Н. Малафеевская // Известия РАН. Серия литературы и языка. - 2014. - Т. 3. № $6 .-$ C. $23-37$.

6. Захаров, В. Н. Канонический текст Достоевского / В. Н. Захаров // Новые аспекты в изучении Достоевского : сб. науч. трудов. - Петрозаводск : Изд-во ПетрГУ, 1994. С. $355-359$.

7. Захаров, В. Н. Текстология как технология / В. Н. Захаров // Проблемы исторической поэтики. Этнологические аспекты / В. Н. Захаров. - Москва : Индрик, 2012. С. $205-221$.

8. Проблемы текстологии Ф. М. Достоевского. Вып. 1 : проблемы текстологии романов «Преступление и Наказание», «Идиот», «Бесы» / М. В. Заваркина, Т. А. Радченко, А. И. Солопова, Н. А. Тарасова ; отв. ред. В. Н. Захаров. - Петрозаводск : Изд-во ПетрГУ, 2009. - 200 с. 
9. Проблемы текстологии Ф. М. Достоевского. Вып. 2 : роман «Подросток» / М. В. Заваркина, В. С. Зинкова, Т. А. Радченко, А. И. Солопова ; отв. редактор В. Н. Захаров. - Петрозаводск : Изд-во ПетрГУ, 2012. - 96 с.

10. Солопова, А. И. Роман Ф. М. Достоевского «Подросток» : проблема канонического текста / А. И. Солопова // Ученые записки ПетрГУ. Серия Обществ. и гуманит. науки. - 2014. - № 5 (142). - С. 86-90.

11. Тарасова, Н. А. Знак тире в наборной рукописи «Дневника писателя» за 1877 г. : особенности пунктуации Достоевского / Н. А. Тарасова // Известия Уральского федерального университета. Серия 2 : Гуманитарные науки. - 2011. - Т. 87. - № 1. C. 89-95.

12. Тарасова, Н. А. Знание и понимание языковых и графических характеристик текста: проблемы чтения рукописей Ф. М. Достоевского / Н. А. Тарасова // Знание. Понимание. Умение. - 2011. - № 2. - С. 135-140.

13. Тарасова, Н. А. Проблема творческого процесса в исследованиях о Достоевском / Н. А. Тарасова // «Дневник писателя» Ф. М. Достоевского (1876-1877) : критика текста. - Москва : Квадрига, 2011. - С. 227-332.

14. Тарасова, Н. А. Проблема установления последовательности записей в рукописях Ф. М. Достоевского (на материале романа «Подросток» и «Дневника писателя» 1876-1877 гг.) / Н. А. Тарасова // Вестник Православного Свято-Тихоновского гуманитарного университета. Серия 3 : Филология. - 2011. - № 25. - С. 96-106.

15. Тарасова, Н. А. Исправления неверных прочтений рукописного текста Достоевского (на материале романов «Бесы» и «Братья Карамазовы») / Н. А. Тарасова // Проблемы исторической поэтики. - Петрозаводск : Изд-во ПетрГУ, 2012. - Вып. 10 : Евангельский текст в русской литературе XVIII-XX веков : цитата, реминисценция, мотив, сюжет, жанр. Вып. 7. - С. 163-172.

16. Тарасова, Н. А. Проблемы текстологического изучения рукописного и печатного текста Ф. М. Достоевского / Н. А. Тарасова // Ученые записки ПетрГУ. Серия Обществ. и гуманит. науки. - 2012. - Т. 2. — № 7 (128). - С. 80-84.

17. Тихомиров, Б. Н. Неизвестный набросок Достоевского к неосуществленному замыслу («<Статьи об отношении России к Европе и об русском верхнем слое >») / Б. Н. Тихомиров // Достоевский. Материалы и исследования. - Т. 15. - Санкт-Петербург, 2000. - С. 334-339.

18. Тихомиров, Б. Н. Задачи и проблемы издания записных книжек и тетрадей Ф. М. Достоевского / Б. Н. Тихомиров // Вестник РГНФ. - 2010. - № 1 (58). - С. 101-115.

19. Тихомиров, Б. Н. Другой Свидригайлов : неосуществленный замысел Достоевского начала 1867 года (наблюдения и гипотезы) / Б. Н. Тихомиров // Три века русской литературы : актуальные аспекты изучения. Ф. М. Достоевский : о творчестве и судьбе : к 190-летию со дня рождения. - Вып. 25. - Москва ; Иркутск, 2011. С. $141-152$.

20. Тихомиров, Б. Н. Сложный случай атрибуции наброска к роману «Бесы» / Б. Н. Тихомиров // Неизвестный Достоевский [Электронный ресурс] : международный электронный журнал. - 2014. - № 1-2. - C. 116-123. - URL : http://unknowndostoevsky.ru/files/redaktor_pdf/1438178527.pdf (28.09.2015). 